\title{
REVIEW
}

GENETICS IN ENDOCRINOLOGY

\section{Genetics of mineralocorticoid excess: an update for clinicians}

\author{
Maria-Christina Zennaro ${ }^{1,2,3}$, Amanda Jane Rickard ${ }^{1,2}$ and Sheerazed Boulkroun ${ }^{1,2}$ \\ ${ }^{1}$ INSERM, UMRS_970, Paris Cardiovascular Research Center, 56 Rue Leblanc, 75015 Paris, France, ${ }^{2}$ Université Paris Descartes, \\ Sorbonne Paris Cité, Paris, France and ${ }^{3}$ Assistance Publique-Hôpitaux de Paris, Hôpital Européen Georges Pompidou, Paris, France \\ (Correspondence should be addressed to M-C Zennaro at INSERM, UMRS_970, Paris Cardiovascular Research Center; \\ Email: maria-christina.zennaro@inserm.fr)
}

\begin{abstract}
Aldosterone plays a major role in the regulation of sodium and potassium homeostasis and blood pressure. More recently, aldosterone has emerged as a key hormone mediating end organ damage. In extreme cases, dysregulated aldosterone production leads to primary aldosteronism (PA), the most common form of secondary hypertension. However, even within the physiological range, high levels of aldosterone are associated with an increased risk of developing hypertension over time. PA represents the most common and curable form of hypertension, with a prevalence that increases with the severity of hypertension. Although genetic causes underlying glucocorticoid-remediable aldosteronism, one of the three Mendelian forms of PA, were established some time ago, somatic and inherited mutations in the potassium channel GIRK4 have only recently been implicated in the formation of aldosteroneproducing adenoma (APA) and in familial hyperaldosteronism type 3. Moreover, recent findings have shown somatic mutations in two additional genes, involved in maintaining intracellular ionic homeostasis and cell membrane potential, in a subset of APAs.

This review summarizes our current knowledge on the genetic determinants that contribute to variations in plasma aldosterone and renin levels in the general population and the genetics of familial and sporadic PA. Various animal models that have significantly improved our understanding of the pathophysiology of excess aldosterone production are also discussed. Finally, we outline the cardiovascular, renal, and metabolic consequences of mineralocorticoid excess beyond blood pressure regulation.
\end{abstract}

European Journal of Endocrinology 169 R15-R25

\section{Background}

\section{Statement}

Aldosterone is a major cardiovascular risk factor. In extreme cases, dysregulated aldosterone production leads to PA, the most common form of secondary hypertension. Major advancements have recently improved our understanding of the genetic determinants contributing to variations in plasma aldosterone levels in the general population as well as the genetics of familial and sporadic PA.

Aldosterone acts on epithelial cells, particularly in the renal collecting duct, but also in the colon and salivary and sweat glands. In these tissues, aldosterone plays a major role in the promotion of sodium absorption and thus regulation of blood pressure. More recently, aldosterone has also emerged as a key hormone determining end organ damage. Aldosterone is synthesized from cholesterol in the zona glomerulosa of the adrenal cortex by a series of specific enzymatic reactions, whereas cortisol is synthesized in zona fasciculata (1). The final steps of aldosterone biosynthesis are catalyzed by aldosterone synthase (encoded by CYP11B2), whereas 11ß-hydroxylase (encoded by CYP11B1) is responsible for the final steps of cortisol biosynthesis. These enzymes are highly homologous and their genes are located in tandem on the chromosome 8q21-22.

Aldosterone biosynthesis is tightly regulated; the principal regulators are the renin-angiotensin system (RAS), extracellular potassium $\left(\mathrm{K}^{+}\right)$concentration, and ACTH. Additional factors (dopamine, serotonin, etc.) have also been shown to modify aldosterone production (2). Stimulation by angiotensin II (AngII) or $\mathrm{K}^{+}$results in depolarization of the zona glomerulosa cell membrane and opening of voltage-dependent $\mathrm{Ca}^{2+}$ channels, leading to an increased intracellular $\mathrm{Ca}^{2+}$ concentration. AngII also signals through the AngII type 1 receptors (AT1Rs) to stimulate inositol trisphosphate-dependent $\mathrm{Ca}^{2+}$ release from the endoplasmic reticulum. Activation of the calcium signaling pathway triggers a phosphorylation cascade that leads to positive regulation of CYP11B2 transcription (Fig. 1A). 
A



B
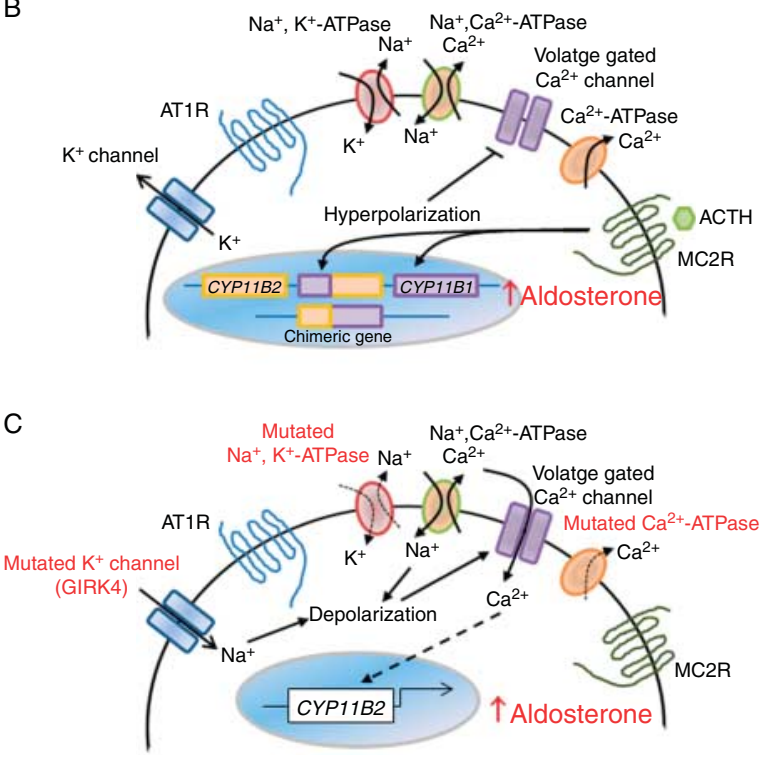

Figure 1 Regulation of aldosterone biosynthesis in normal and pathological conditions. (A) Stimulation of aldosterone production by angiotensin II (Angll). Angll binds to the Angll type 1 receptor (AT1R), leading to zona glomerulosa cell membrane depolarization, by a number of converging mechanisms. The inhibition of potassium channels and sodium potassium ATPase $\left(\mathrm{Na}^{+}, \mathrm{K}^{+}\right.$-ATPase $)$by Angll results in depolarization of the cell membrane and opening of voltagedependent $\mathrm{Ca}^{2+}$ channels, which ultimately lead to an increase in intracellular $\mathrm{Ca}^{2+}$ concentration. Activation of AT1R stimulates inositol triphosphate-dependent $\mathrm{Ca}^{2+}$ release from the endoplasmic reticulum. Activation of the calcium signaling pathway leads to the activation of specific transcription factors and positive regulation of CYP11B2 transcription. (B) Genetic alteration in familial hyperaldosteronism type I ( $\mathrm{FH}-\mathrm{I})$. $\mathrm{FH}-\mathrm{I}$ is caused by a recombination between the CYP11B2 and CYP11B1 genes, creating a chimeric gene whereby the CYP11B1 promoter and CYP11B2-specific coding sequences are juxtaposed, leading to inappropriate regulation of aldosterone synthesis; aldosterone biosynthesis is regulated by the ACTH, rather than by Angll. (C) Genetic alterations leading to cell membrane depolarization and intracellular ionic modification. $\mathrm{FH}$-III is the result of a gain of function mutation in the KCNJ5 gene, which encodes the G-protein-activated inward rectifier potassium channel GIRK4. In addition to germline mutations in patients with $\mathrm{FH}-\mathrm{III}$, a few recurrent somatic KCNJ5 mutations were identified in a large proportion of sporadic aldosterone-producing adenomas. The recent identification of somatic mutations in two different ATPase genes, namely ATP1A1 and ATP2B3, encoding the $\alpha 1$ subunit of the $\mathrm{Na}^{+}, \mathrm{K}^{+}$-ATPase and the plasma membrane $\mathrm{Ca}^{2+}$-ATPase PMCA3 respectively, indicates that potassium channels are not the only regulators of cell membrane depolarization. Interestingly, all these mutations lead to an increase in intracellular $\mathrm{Ca}^{2+}$ concentration and consequently positive regulation of CYP11B2. Full arrows, direct activation; hatched arrows, indirect activation requiring intermediary steps.
In this review, we explore the role of genetic mechanisms in aldosterone production and mineralocorticoid excess and the pathological consequences of excess aldosterone in terms of cardiovascular disease, renal damage, and metabolic abnormalities.

\section{Genetic contribution to plasma aldosterone levels and the aldosterone-to-renin ratio}

Recent epidemiological studies have shown that plasma aldosterone and renin levels and the aldosteroneto-renin ratio (ARR) correlate with increased blood pressure and the incidence of hypertension in the general population $(3,4,5)$. This suggests that modifications in adrenal aldosterone production may contribute to blood pressure elevation in a significant proportion of hypertensive subjects. Genetic variations in genes related to aldosterone biosynthesis may account for differences in aldosterone levels. In addition to clinical parameters, which are highly correlated with plasma aldosterone and renin levels, i.e. age, salt intake, and use of $\beta$-blockers, diuretics, and ACE inhibitors, gender is a major contributor to plasma renin and aldosterone levels and the $\operatorname{ARR}(3,6)$. In the Framingham Heart Study, the heritability of aldosterone levels, i.e. the proportion of variation in the population that is due to genetic differences, was estimated at $11 \%$, that of renin levels at $22 \%$, and that of the ARR at $40 \%$. Genetic analysis has identified two chromosomal regions with a modest linkage to the ARR on chr 11p and $5 \mathrm{p}$. In this study, the REN locus (coding for renin) and the CYP11B2 locus had no significant linkage to either parameter. When measuring 24-h urinary excretion of key metabolites of the principal mineralocorticoids and glucocorticoids, the heritability of tetrahydroaldosterone excretion was significantly higher $(52 \%)$ and there was a significant association with the genotype at several polymorphisms of the CYP11B1 and CYP11B2 loci (7). More recently, we have shown that a common single-nucleotide polymorphism (SNP), i.e. a DNA sequence variation at a single nucleotide within the general population, the c. 2G >C (rs2070951) of the NR3C2 gene coding for the mineralocorticoid receptor (MR), is associated with plasma renin levels, both in a mild hypertensive group and in normal volunteers; in the latter group, the GG genotype was also correlated with higher plasma aldosterone levels (8). This association implies an indirect mechanism whereby modifications in renal sodium homeostasis, due to genetic variation affecting MR expression, modulate aldosterone production in the adrenal cortex in an endocrine regulatory loop. Furthermore, recent data suggest that blood pressure and aldosterone production may be affected by genetic variations in KCNK9, coding for the potassium channel TWIK-related acid-sensitive potassium 3 (TASK3), one 
of the main potassium channels involved in maintaining the glomerulosa cell membrane potential and thus aldosterone production (see below (9) and D Vernerey, X Jeunemaitre, J Barhanin, P Meneton and M-C Zennaro, 2011, unpublished data).

Analysis of the $5^{\prime}$ flanking region of the human CYP11B2 gene has defined the different regulatory elements involved in its expression (10). Interestingly, several polymorphic variations in the CYP11B2 gene promoter that affect aldosterone levels have been described (11). In particular, the $-344 \mathrm{~T} / \mathrm{C}$ polymorphism has been studied extensively. This polymorphism is localized in a putative binding site of the steroidogenic factor SF-1. In vitro studies have shown that the $-344 \mathrm{C}$ allele binds to SF-1 with approximately four times higher affinity than the $-344 \mathrm{~T}$ allele, possibly altering the rate of transcription of CYP11B2 and therefore the amount of aldosterone synthase $(11,12)$. Studies have shown that carriers of a $\mathrm{T}$ at position -344 have an increased risk of hypertension and that the polymorphism is more frequent in hypertensive subjects than in normotensive subjects $(13,14)$. Moreover, the $-344 \mathrm{~T}$ allele is also associated with significant differences in plasma aldosterone levels and in the excretion of urinary metabolites of aldosterone, supporting the possibility of increased aldosterone synthase activity $(15,16)$. Another common variant on intron 2 of the CYP11B2 gene exists in two alternate forms, either a wild-type or a conversion (Conv) allele, where part of intron 2 of CYP11B1 is transferred to CYP11B2 (11). This variant is in tight linkage disequilibrium with the $-344 \mathrm{C} / \mathrm{T}$ allele, and hence the $-344 \mathrm{~T}$ and Conv alleles in intron 2 have been shown to be associated with hypertension, an elevated aldosterone:renin ratio, and increased aldosterone levels in young adults (17). Finally, an SNP at position -1651 of CYP11B2, which is in tight linkage disequilibrium with the -344 SNP, exerts significant allele-dependent effects on CYP11B2 transcription and aldosterone production. This is due to changes in the binding of the transcriptional repressor APEX1 to this site depending on the genotype (18).

Polymorphic variations in the CYP11B2 gene are also associated with left ventricular size, mass, and, to some extent, diastolic function in subjects without clinical cardiovascular disease. These effects are independent of potentially confounding factors, including sex, body weight, blood pressure, physical activity, smoking, and alcohol consumption (17). These findings, however, are not consistent in all studies, which may be due to selection biases $(19,20)$. Furthermore, there are conflicting reports in the literature as to whether the T or $\mathrm{C}$ allele is more prevalent in patients with hypertension $(13,21)$. These differences are most likely to depend on the origin of the population, as different allele frequencies have been reported in different populations $(19,22)$. A recent meta-analysis has shown that the $-344 \mathrm{C}$ allele is associated with a $17 \%$ reduced relative risk of hypertension compared with the $-344 \mathrm{~T}$ allele (23). A significantly lower plasma renin activity has also been associated with the $-344 \mathrm{C}$ allele, whereas plasma aldosterone concentration has not. Thus, different common genetic polymorphisms may underlie the observed relationship between the CYP11B2 genotype and aldosterone production and therefore may contribute to the risk of developing hypertension and cardiovascular disease in the general population.

\section{Familial forms of primary aldosteronism}

Primary aldosteronism (PA) is the most common form of secondary hypertension with a prevalence of $\sim 10 \%$ of all hypertensives and $\sim 20 \%$ when considering patients with resistant hypertension (24). It is associated with a suppressed RAS and often with hypokalemia. PA is due to autonomous aldosterone production by the adrenal cortex. The two principal forms are unilateral aldosterone-producing adenoma (APA or Conn's adenoma), a benign tumor of the adrenal cortex, and bilateral adrenal hyperplasia (BAH), also known as idiopathic hyperaldosteronism. While the majority of cases are sporadic, $1-10 \%$ of the cases are familial forms. Currently, three different forms displaying Mendelian inheritance are described: familial hyperaldosteronism type I (FH-I), type II (FH-II), and type III (FH-III).

\section{Familial hyperaldosteronism type I}

In 1966, Sutherland et al. (25) reported a case of a father and a son presenting with benign hypertension, hypokalemia, increased aldosterone levels, and suppressed plasma renin activity, indicative of PA. Interestingly, all abnormalities were relieved by treatment with dexamethasone. FH-I, also called glucocorticoidremediable aldosteronism (GRA), presents an autosomal dominant mode of inheritance (26). The disorder is characterized by early and severe hypertension, most often before the age of 20 years. Subjects exhibit, to variable intensities, the biochemical abnormalities of $\mathrm{PA}$ and in some cases adrenal nodules and significant production of the hybrid steroids 18-hydroxycortisol and 18-oxocortisol (25). FH-I is caused by a recombination between the CYP11B2 and CYP11B1 genes, creating a chimeric gene whereby the CYP11B1 promoter and CYP11B2-specific coding sequences are juxtaposed, leading to inappropriate regulation of aldosterone synthesis (27) (Fig. 1B). Given that the regulatory sequences are derived from CYP11B1, it is presumed that the hybrid gene is expressed throughout the adrenal cortex (28). In FH-I, aldosterone biosynthesis is regulated by the ACTH, rather than by AngII. The regulation of aldosterone by ACTH in FH-I results in a circadian pattern of aldosterone production, which parallels that of cortisol production (29). The administration of exogenous glucocorticoids, to suppress ACTH 
secretion, reduces aldosterone levels and reverses the state of mineralocorticoid excess. However, the lowest possible dose of glucocorticoids, which normalize blood pressure and/or serum potassium concentration, should be used to avoid complete suppression of the circadian regulation of cortisol. Indeed, overtreatment with exogenous steroid may result in iatrogenic Cushing's syndrome and impaired linear growth in children (30). Remarkably, low-dose glucocorticoid treatment has been shown to control hypertension for several years, as supported by normal and stable echocardiographic parameters (29). The addition of an MR antagonist, however, should be considered in cases where blood pressure control is unsatisfactory. In the case of affected children, the use of eplerenone may be preferred to avoid the side effects of glucocorticoids (growth retardation) and spironolactone (antiandrogenic effects) (30).

The prevalence of FH-I in patients with PA has been reported to be between 0.66 and $1 \%(28,31)$ and as high as $3.1 \%$ in a hypertensive pediatric population, in which the prevalence of FH may be underdiagnosed (32). Following the Endocrine Society guidelines for the management of PA, genetic testing for GRA should be considered for PA patients with severe or resistant hypertension and a positive family history of early-onset hypertension and/or premature hemorrhagic stroke (30). However, the blood pressure in GRA-affected subjects within and between pedigrees is often highly variable; while most are severely hypertensive, some affected individuals are normotensive and others display only mild hypertension. This variability in blood pressure levels in GRA may be related to other hereditary factors that regulate blood pressure or environmental factors such as variations in dietary sodium intake. Thus, the family history in GRA does not invariably reveal a history of severe hypertension in first-degree relatives of affected subjects.

The diagnosis of GRA is usually made by either Southern blot or long PCR techniques, both sensitive and specific tests for diagnosing GRA, obviating the need to measure the urinary levels of 18-oxocortisol and 18-hydroxycortisol or to perform a dexamethasone suppression test, both of which may be misleading (30).

\section{Familial hyperaldosteronism type II}

In 1991, a second form of $\mathrm{FH}$, which was not glucocorticoid remediable, was described (33). As with FH-I, an autosomal dominant mode of transmission was observed. Patients with FH-II demonstrate a variable aldosterone response to upright posture and AngII infusion, and within the same family, different subtypes of PA may be represented (APA and BAH). Patients with FH-II, however, do not display specific clinical, biochemical, or morphological hallmarks that distinguish them from sporadic cases of PA, and hence FH-II is diagnosed on the basis of two or more affected family members; phenotypic variability within affected families is typical for the disease $(31,34)$. The prevalence of FH-II is estimated to be between 2.8 and $6 \%$ in adult populations of PA $(31,34,35)$. Although the molecular basis of FH-II is still unknown, a link with the chromosomal region $7 \mathrm{p} 22$ has been established in some, but not all, FH-II families $(36,37,38)$. Sequencing candidate genes located in this region, fascin 1 (FSCN1) and the cAMP-dependent protein kinase type I $\beta$-regulatory subunit (PRKAR1B), revealed no mutations (34). Furthermore, mutations have not been identified in the coding region of CYP11B2 or AGTR1, coding for the AT1R, or in the p53 tumorsuppressor gene $(35,39,40)$. Interestingly, somatic mutations of KCNJ5 (see below) have recently been reported in APA samples from patients with nonglucocorticoid-suppressible $\mathrm{FH}$ that was classified as FH-II (41). This raises the possibility that FH-II might be due, at least in some cases, to familial aggregation of sporadic PA, given the high frequency of the disease among hypertensive subjects. Furthermore, another subgroup of families was shown to have FH-III upon genetic diagnosis, due to a previously unknown phenotypic heterogeneity of this latter form of familial PA (41).

\section{Familial hyperaldosteronism type III}

In 2008, a new form of FH was described (42). The affected family members presented with early-onset, severe hypertension, which was resistant to treatment, and profound hypokalemia. Furthermore, they exhibited very high levels of the hybrid steroids 18-oxocortisol and 18-hydroxycortisol and aldosterone production was not suppressed by dexamethasone treatment. Hyperaldosteronism was shown to be a consequence of massive $\mathrm{BAH}$, which required a bilateral adrenalectomy to control blood pressure (42). Recently, the origin of FH-III has been attributed to a mutation in the KCNJ5 gene, which encodes for the G-protein-activated inward rectifier potassium channel GIRK4 (43). This mutation, p.T158A, is located just above the selectivity filter of the channel and results in the loss of $\mathrm{K}^{+}$ion selectivity and increased $\mathrm{Na}^{+}$conductance. As the membrane potential of the zona glomerulosa cell is close to the potassium resting potential, an increase in sodium conductance, which is associated with the p.T158A mutation, leads to membrane depolarization, opening of voltage-dependent calcium channels, and activation of the calcium signaling pathway, the main trigger for aldosterone biosynthesis (44) (Fig. 1C). Subsequently, additional mutations and phenotypic variability in FH-III have been reported. An inherited p.G151R mutation was identified in two kindreds with early and severe hyperaldosteronism that was due to $\mathrm{BAH}$ and required a bilateral adrenalectomy during childhood to control blood pressure (45). A similar severe phenotype of primary hyperaldosteronism and 
early-onset hypertension was associated with a p.I157S mutation (46), while a third germline mutation, p.G151E, was associated with familial aldosteronism in three families $(41,45)$. Interestingly, these mutations are all located in and near the selectivity filter of GIRK4, which would presumably lead to the same pathological consequences in terms of channel function. The affected members of the families with the p.G151E mutation, however, exhibit remarkably milder symptoms compared with the patients carrying the other mutations, with blood pressure and hypokalemia being easily controlled with medical treatment and no evidence of adrenal cortex hyperplasia. This clinical presentation, resembling $\mathrm{FH}-\mathrm{II}$, revealed a previously unrecognized phenotypic heterogeneity of FH-III; additional genetic investigations in affected families will allow delineating the clinical spectrum of this form of FH.

\section{Potassium channels, ATPases, and the new biology of sporadic APA}

As mentioned above, the maintenance of an appropriate zona glomerulosa cell membrane potential is crucial for the regulation of aldosterone biosynthesis. Cell membrane depolarization is one of the main triggers for the chain of intracellular events that ultimately leads to increased aldosterone biosynthesis. In the adrenal zona glomerulosa, the main ionic conductance is that of $\mathrm{K}^{+}$, due to the expression of different types of $\mathrm{K}^{+}$channels. As a consequence, the cell membrane potential closely follows the equilibrium potential of $\mathrm{K}^{+}$over a large range of extracellular $\mathrm{K}^{+}$concentrations. Among others, the physiological role of TASK channels has recently been highlighted by studies in various animal models in which genetic ablation of the channels results in a range of phenotypes with abnormal aldosterone production $((47,48,49)$, see below). The concentration gradient of $\mathrm{K}^{+}$between the intracellular and extracellular spaces, which is required for the establishment of the membrane potential, is generated by the activity of the $\mathrm{Na}^{+}, \mathrm{K}^{+}$-ATPase, which transports two $\mathrm{K}^{+}$ions into and three $\mathrm{Na}^{+}$ions out of the cell. Recently, mutations in different genes coding for proteins involved in the regulation of the zona glomerulosa cell membrane potential and ionic homeostasis have been identified in tumoral (somatic) DNA from sporadic APA.

In addition to germline mutations in patients with FH-III, a few recurrent somatic KCNJ5 mutations were identified in a large proportion of sporadic APAs (43, 50). Similarly to the germline mutations, the p.G151R and p.L168R mutations are located within or near the selectivity filter of the GIRK channel, which results in the loss of $\mathrm{K}^{+}$ion selectivity. These mutations are present in $34-47 \%$ of the APA samples from Western countries $(50,51,52,53)$ and as high as $65 \%$ of patients from Japan (54) (Table 1). KCNJ5 mutations in APA are more prevalent in females than in males and in younger patients; they are also associated with higher preoperative aldosterone levels but not with therapeutic outcomes after surgery (50). Although some authors have reported association of the mutation status with differences in KCNJ5 mRNA or protein expression in the tumor, these findings are not consistent among studies (Table 1). While germline KCNJ5 mutations result in $\mathrm{BAH}$ in familial forms of the disease, similar mutations have, however, not been identified in patients with $\mathrm{BAH}$, the other most frequent form of sporadic PA (50).

More recently, somatic mutations in two members of the P-type ATPase gene family, namely ATP1A1, encoding the $\alpha 1$ subunit of the $\mathrm{Na}^{+}, \mathrm{K}^{+}$-ATPase, and

Table 1 Frequency and clinical and biological correlations of somatic KCNJ5 mutations in APA.

\begin{tabular}{|c|c|c|c|c|c|c|c|}
\hline $\begin{array}{l}\text { No. of APA } \\
\text { samples }\end{array}$ & $\begin{array}{c}\text { Mutation } \\
\text { frequency (\%) }\end{array}$ & $\begin{array}{l}\text { Gender } \\
\text { differences }\end{array}$ & Age & Tumor size & $\begin{array}{l}\text { Clinical } \\
\text { correlates }\end{array}$ & $\begin{array}{l}K C N J 5 \text { protein or } \\
\text { mRNA expression }\end{array}$ & References \\
\hline 380 & 34 & $\mathrm{~F}>\mathrm{M}$ & Younger & $=$ & $\begin{array}{l}\uparrow \text { preop plasma } \\
\text { aldosterone }\end{array}$ & $\begin{array}{l}\text { No correlation } \\
\text { (mRNA); } \downarrow \\
\text { expression } \\
\text { (protein) }\end{array}$ & $(50,82)$ \\
\hline 348 & 45 & $\mathrm{~F}>\mathrm{M}$ & $\begin{array}{l}\text { Younger in } \\
\text { male carriers }\end{array}$ & $\begin{array}{r}\uparrow \text { in male } \\
\text { carriers }\end{array}$ & NA & $\begin{array}{l}\text { No correlation } \\
\text { (protein) }\end{array}$ & (52) \\
\hline 73 & 41 & $\mathrm{~F}>\mathrm{M}$ & Younger & $\uparrow$ & $\begin{array}{l}\text { Unresponsive to } \\
\text { upright posture }\end{array}$ & Not tested & $(51,83)^{a}$ \\
\hline 47 & 38 & $\mathrm{~F}>\mathrm{M}$ & $=$ & NA & $\begin{array}{l}\downarrow \text { preop serum } \\
\text { potassium }\end{array}$ & $\begin{array}{l}\text { No correlation } \\
\text { (mRNA and } \\
\text { protein) }\end{array}$ & (53) \\
\hline 23 & 65 & No & Younger & $=$ & $\begin{array}{l}\uparrow \text { preop plasma } \\
\text { aldosterone; } \\
\downarrow \text { preop serum } \\
\text { potassium }\end{array}$ & $\begin{array}{l}\uparrow K C N J 5 \text { (mRNA } \\
\text { and protein) }\end{array}$ & (54) \\
\hline 22 & 36 & NS & NS & $=$ & NA & NA & (43) \\
\hline
\end{tabular}

F, females; M, males; NA, not available; NS, not significant; $\uparrow$, increased; $\downarrow$, decreased; =, no change; preop, preoperative. Only studies including more than 20 APA samples are presented.

a These two studies share 46 patients; correlations refer to this subset of patients (83), except the response to upright posture, which refers to the remaining 27 patients mentioned in (51). 
ATP2B3, coding for the plasma membrane calciumtransporting ATPase 3 (PMCA3), have been identified. This finding highlights their role in the regulation of aldosterone production by maintaining intracellular ionic homeostasis and zona glomerulosa cell membrane potential. Two mutations were identified in ATP1A1, a Leu104Arg and a Val332Gly substitution; they are located in the transmembranous $\alpha$-helix M1 or the juxtaposed $\alpha$-helix M4, both of which have been suggested to interact and cooperate with potassium ion binding and gating. An additional small deletion, p.Phe100_Leu104del, overlapping Leu104 was also identified. Different overlapping in-frame deletions in ATP $2 B 3$ resulted in the deletion of two amino acids (p.Leu425_Val426del or p.Val426_pVal427del). Both ATPases are highly expressed in the adrenal cortex. In vitro experiments in cell models indicated that mutations in the $\alpha 1$ subunit of the $\mathrm{Na}^{+}, \mathrm{K}^{+}$-ATPase led to a complete loss of pump activity and a strongly reduced affinity for $\mathrm{K}^{+}$. Furthermore, electrophysiological studies performed on primary adrenal adenoma cells demonstrated an inappropriate depolarization of cells with ATP1A1 mutations. Deletions in ATP2B3 were predicted to affect the homologous M4 transmembrane domain of PMCA3 and to cause a major distortion of the $\mathrm{Ca}^{2+}$ binding site, therefore affecting intracellular calcium clearance. ATP1A1 and ATP2B3 mutations were found in $6.8 \%$ of the 308 APA samples investigated and exclusively in KCNJ5-negative tumors. In contrast to KCNJ5 mutations, ATPase mutations were more prevalent in males than in females. They were also associated with a more severe phenotype: carriers of ATPase mutations had higher preoperative aldosterone levels compared with patients without mutations and lower serum potassium concentrations. No mutations were identified in patients with familial or bilateral forms of PA (55).

\section{Mineralocorticoid excess: insights from animal models}

The recent identification of recurrent somatic mutations in the KCNJ5 gene in APA, as well as germline mutations of the same gene in families with FH-III, has constituted a major advance in our understanding of the disease $(41,43,46,50,52,56)$. It confirmed the role of potassium channels in the development of PA, which had previously been highlighted by different mouse models. Indeed, genetic invalidation of the TASK1 channel in mice leads to adrenocortical cell depolarization and ectopic expression of Cyp11B2 in zona fasciculata in female mice only (47). Interestingly, female Kcnk3 homozygous knockout $\left(\mathrm{TASK} 1^{-/-}\right)$mice display a diet-independent, low-renin, and glucocorticoid-remediable form of hyperaldosteronism. Until puberty, male TASK $1^{-/-}$ mice show the same phenotype, but subsequently develop normally in terms of adrenal zonation and steroid secretion, suggesting a critical role for androgens in terms of the compensatory mechanisms employed following Kcnk3 gene disruption (47). The genetic deletion of both TASK1 and TASK3 channels in mice leads to $\mathrm{ZG}$ membrane depolarization due to the absence of recordable acid-sensitive $\mathrm{K}^{+}$current (48). Task1/Task3 (Kcnk3/Kcnk9) double-knockout mice display elevated levels of aldosterone and low circulating renin and fail to suppress aldosterone production by dietary salt ingestion. Taken together, TASK $1 /$ TASK $^{-/-}$ mice present a phenotype reminiscent of patients with idiopathic primary hyperaldosteronism (48). Finally, mice lacking TASK3 channels only display a mild hyperaldosteronism that is associated with low renin levels and an increased ARR. These animals display partially autonomous aldosterone production, which is not suppressed by high-sodium or low-potassium diets (49). It is likely that the constitutively depolarized state of glomerulosa cells in TASK $3^{-1-}$ animals leads to partially autonomous aldosterone production, which is counterbalanced by a decreased activity of the renin-angiotensin axis. Despite the fact that these models suggest that abnormalities in TASK1 and/or TASK3 in humans may be involved in the pathogenesis of PA, sequencing of these genes in 22 patients with APA (43) has not led to the identification of any causative mutations.

Up to $10 \%$ of the transcriptome has been estimated to be under the control of the circadian clock, so it is therefore not surprising that a number of diseases are associated with clock gene disorders (57). Cry proteins act as potent transcriptional repressors that downregulate the transcription of E-box (CACGTG) enhancer-containing clock genes (including the Periodand Cryptochrome-encoding genes), as well as a wide variety of clock-controlled genes (58, 59). Mice lacking the core clock components cryptochrome-1 (Cry1) cryptochrome-2 (Cry2, Cry-null mice) show disrupted rhythmic behavior, physiology, and metabolism (60, 61). Interestingly, Cry-null mice present with salt-sensitive hypertension due to increased aldosterone production by the adrenal gland (62). Investigation of steroidogenic alterations in Cry-null mice showed chronic overexpression of Hsd3b6 mRNA and chronically enhanced $3 \beta$-hydroxysteroid dehydrogenase activity in adrenal cortex. Hsd3b6 encodes a dehydrogenase-isomerase specifically expressed in zona glomerulosa, which catalyzes the conversion of pregnenolone into progesterone, an enzymatic reaction required for aldosterone biosynthesis. The inactivation of Cry genes leads to chronically enhanced mineralocorticoid production, which, in turn, renders blood pressure salt sensitive (62). The human ortholog of mouse Hsd3b6 is HSD3B1. In the adrenal cortex, expression of $H S D 3 B 1$ is specific to the zona glomerulosa, suggesting its potential involvement in adrenal zona glomerulosa pathophysiology. 
The RAS is a major regulator of aldosterone biosynthesis. The role of the RAS has been investigated in numerous experimental mouse models $(63,64,65)$. Mice lacking the AngII receptor type 1A (AT1A receptor) have low blood pressure (63), whereas female mice overexpressing AT1A receptor display high blood pressure (64). Mice expressing a constitutively active AT1A receptor develop renal and cardiac fibrosis and diastolic dysfunction and present with a moderate and stable increase in blood pressure. This hypertension is associated with a low plasma renin concentration and a normal aldosterone concentration, leading to an increase in plasma ARR (65). These results suggest that, in humans, modifications or defects in the RAS may contribute to the high-aldosterone, low-renin form of hypertension and, in extreme cases, to mineralocorticoid excess.

\section{Pathological consequences of mineralocorticoid excess beyond blood pressure}

In addition to the well-characterized effects of excess mineralocorticoids on blood pressure, high levels of circulating aldosterone also have cardiovascular, renal, and metabolic consequences. The diagnosis of PA and the identification of its subtypes, whether familial or sporadic, APA or BAH, are essential for the setup of efficient therapeutic intervention and prevention of the adverse effects of aldosterone. Patients with PA are at an increased risk of developing cardiovascular events, such as atrial fibrillation, stroke, and non-fatal myocardial infarction, when compared with patients with other forms of hypertension, despite equivalent blood pressure elevation (66). A recent study using cardiac magnetic resonance imaging has demonstrated that patients with PA exhibit frequent non-infarct myocardial fibrosis that is independent of blood pressure and is associated with increased pulse wave velocity, circulating superoxide anion, and C-reactive proteins (67). Studies have also reported increased cardiovascular and cerebrovascular complications in patients with familial forms of PA. Aldosterone excess is associated with increased left ventricular wall thicknesses and reduced diastolic function, even in the absence of hypertension, in young individuals with genetically proven FH-I (68). In a large study investigating 367 patients from 27 genetically confirmed FH-I pedigrees, early cerebrovascular complications were documented in $48 \%$ of all pedigrees and in $18 \%$ of all FH-I patients. The complications were mainly hemorrhagic strokes and were associated with a high mortality rate (69).

There is accumulating evidence indicating that aldosterone-dependent kidney damage is a major determinant of blood pressure outcome following treatment in patients with PA (70). Prospective studies have reported a higher glomerular filtration rate and albuminuria in patients with APA or BAH compared with essential hypertension and significant reduction in urinary albumin excretion and glomerular filtration rate following adrenalectomy or treatment with spironolactone $(71,72)$. Increased glomerular filtration most likely results from functional changes due to intrarenal hemodynamic adaptation to increased extracellular volume, which counteracts increased tubular sodium absorption by aldosterone to restore sodium balance (73). In the early stage, these changes are largely and rapidly reversible $(71,72)$. At a later stage, however, aldosterone induces intrarenal vascular and glomerular damage, with progressive renal impairment and reduction of glomerular filtration rate (74), which is correlated with blood pressure response to treatment and the risk of developing chronic kidney disease (75). These studies underscore the importance of specific treatment of aldosterone excess as well as blood pressure reduction to minimize cardiovascular and renal morbidity in PA.

Studies exploring the prevalence of metabolic abnormalities in patients with PA remain controversial and await definitive evidence. Several studies have reported a higher prevalence of the metabolic syndrome in PA patients compared with essential hypertensive patients $(76,77)$, with the prevalence of the metabolic syndrome and increased BMI being greater in BAH than in APA (76). Impaired glucose metabolism and increased insulin resistance, which correlate with aldosterone levels, have also been reported $(76,78)$. Investigation of 338 patients with PA from the German Conn's registry showed a higher prevalence of diabetes mellitus in patients with PA than in hypertensive controls (79). However, in a recent retrospective study comparing 460 cases of PA with 1363 cases of essential hypertension, Matrozova et al. (80) did not detect any difference in the prevalence of hyperglycemia and blood levels of glucose and lipids between the groups. In a prospective study involving $47 \mathrm{PA}$ patients who were followed for an average period of 5.7 years, Catena et al. (81) showed that patients with PA had higher insulin resistance when compared with normotensive controls, but that the defect was less severe than in essential hypertensives.

\section{Conclusions}

Aldosterone has recently emerged as a key hormone mediating end organ damage. Within the physiological range, genetic variation in aldosterone synthase expression may lead to higher levels of aldosterone that are associated with an increased risk of developing hypertension. In extreme cases, autonomous aldosterone production from the adrenal gland leads to PA in up to $10 \%$ of hypertensives. The prompt diagnosis of PA and the identification of its clinical and genetic subtypes are essential for the setup of efficient therapeutic intervention and prevention of the adverse 
cardiovascular and renal effects of aldosterone. Familial forms of PA represent $1-10 \%$ of the cases. FH-I should be considered in PA patients with severe or resistant hypertension and a family history of early-onset hypertension and/or premature hemorrhagic stroke, and FH-III should be suspected in young patients who are negative for FH-I and display marked hyperaldosteronism, hypokalemia, and severe hypertension resistant to medical therapy. In both cases, the genetic diagnosis can efficiently direct treatment options. In contrast, FH-II is undistinguishable from sporadic PA, with no genetic test that is available to date. Somatic genetic testing for KCNJ5, ATP1A1, and ATP2B3 mutations in APA may be of clinical benefit for patients in the future, after prospective studies have evaluated their association with parameters of outcome after surgery. The recent identification of genetic abnormalities in familial and sporadic forms of PA will hopefully lead to the development of novel therapeutic approaches. Understanding the genetic basis of mineralocorticoid excess in endocrine hypertension will help us to develop more powerful diagnostic procedures and possibly innovative therapeutic options, which could benefit up to $10 \%$ of hypertensives.

\section{Declaration of interest}

The authors declare that there is no conflict of interest that could be perceived as prejudicing the impartiality of the research reported.

\section{Funding}

This work was funded through institutional support from INSERM and by the Agence Nationale pour la Recherche (ANR Physio 2007, no.: 013-01; Genopat 2008, no.: 08-GENO-021), the Fondation pour la Recherche sur l'Hypertension Artérielle (AO 2007), the Fondation 6 pour la recherche médicale (ING20101221177), and the Programme Hospitalier de Recherche Clinique (PHRC grant AOM 06179) and by grants from INSERM and Ministère Délégué à la Recherche et des Nouvelles Technologies.

\section{References}

1 Connell JM \& Davies E. The new biology of aldosterone. Journal of Endocrinology 2005186 1-20. (doi:10.1677/joe.1.06017)

2 Quinn SJ \& Williams GH. Regulation of aldosterone secretion. Annual Review of Physiology 198850 409-426. (doi:10.1146/ annurev.ph.50.030188.002205)

3 Newton-Cheh C, Guo CY, Gona P, Larson MG, Benjamin EJ, Wang TJ, Kathiresan S, O'Donnell CJ, Musone SL, Camargo AL et al. Clinical and genetic correlates of aldosterone-to-renin ratio and relations to blood pressure in a community sample. Hypertension $2007 \mathbf{4 9}$ 846-856. (doi:10.1161/01.HYP.0000258554.87444.91)

4 Vasan RS, Evans JC, Larson MG, Wilson PW, Meigs JB, Rifai N, Benjamin EJ \& Levy D. Serum aldosterone and the incidence of hypertension in nonhypertensive persons. New England Journal of Medicine 2004351 33-41. (doi:10.1056/NEJMoa033263)

5 Meneton P, Galan P, Bertrais S, Heudes D, Hercberg S \& Menard J. High plasma aldosterone and low renin predict blood pressure increase and hypertension in middle-aged Caucasian populations. Journal of Human Hypertension 200822 550-558. (doi:10.1038/ jhh.2008.27)
6 Kathiresan S, Larson MG, Benjamin EJ, Corey D, Murabito JM, Fox CS, Wilson PW, Rifai N, Meigs JB, Ricken G et al. Clinical and genetic correlates of serum aldosterone in the community: the Framingham Heart Study. American Journal of Hypertension 2005 18 657-665. (doi:10.1016/j.amjhyper.2004.12.005)

7 Imrie H, Freel M, Mayosi BM, Davies E, Fraser R, Ingram M, Cordell HJ, Farrall M, Avery PJ, Watkins H et al. Association between aldosterone production and variation in the 11ß-hydroxylase (CYP11B1) gene. Journal of Clinical Endocrinology and Metabolism 200691 5051-5056. (doi:10.1210/jc.2006-1481)

8 van Leeuwen N, Caprio M, Blaya C, Fumeron F, Sartorato P, Ronconi V, Giacchetti G, Mantero F, Fernandes-Rosa FL, Simian C et al. The functional c. $-2 \mathrm{G}>\mathrm{C}$ variant of the mineralocorticoid receptor modulates blood pressure, renin, and aldosterone levels. Hypertension 201056 995-1002. (doi:10.1161/HYPERTENSIONAHA.110.155630)

9 Jung J, Barrett PQ, Eckert GJ, Edenberg HJ, Xuei X, Tu W \& Pratt JH. Variations in the potassium channel genes KCNK3 and KCNK9 in relation to blood pressure and aldosterone production: an exploratory study. Journal of Clinical Endocrinology and Metabolism 201297 2160-2167. (doi:10.1210/jc.2012-2196)

10 Clyne CD, Zhang Y, Slutsker L, Mathis JM, White PC \& Rainey WE. Angiotensin II and potassium regulate human CYP11B2 transcription through common cis-elements. Molecular Endocrinology 199711 638-649. (doi:10.1210/me.11.5.638)

11 White PC \& Slutsker L. Haplotype analysis of CYP11B2. Endocrine Research 199521 437-442. (doi:10.3109/07435809509030459)

12 Bassett MH, Zhang Y, Clyne C, White PC \& Rainey WE. Differential regulation of aldosterone synthase and $11 \beta$-hydroxylase transcription by steroidogenic factor-1. Journal of Molecular Endocrinology 200228 125-135. (doi:10.1677/jme.0.0280125)

13 Brand E, Chatelain N, Mulatero P, Fery I, Curnow K, Jeunemaitre X, Corvol P, Pascoe L \& Soubrier F. Structural analysis and evaluation of the aldosterone synthase gene in hypertension. Hypertension 1998 32 198-204. (doi:10.1161/01.HYP.32.2.198)

14 Casiglia E, Basso G, Guglielmi F, Martini B, Mazza A, Tikhonoff V, Scarpa R, Saugo M, Caffi S \& Pessina AC. German origin clusters for high cardiovascular risk in an Italian enclave. International Heart Journal 200546 489-500. (doi:10.1536/ihj.46.489)

15 Paillard F, Chansel D, Brand E, Benetos A, Thomas F, Czekalski S, Ardaillou R \& Soubrier F. Genotype-phenotype relationships for the renin-angiotensin-aldosterone system in a normal population. Hypertension 199934 423-429. (doi:10.1161/01.HYP.34.3.423)

16 Davies E, Holloway CD, Ingram MC, Inglis GC, Friel EC, Morrison C, Anderson NH, Fraser R \& Connell JM. Aldosterone excretion rate and blood pressure in essential hypertension are related to polymorphic differences in the aldosterone synthase gene CYP11B2. Hypertension 199933 703-707. (doi:10.1161/ 01.HYP.33.2.703)

17 Kupari M, Hautanen A, Lankinen L, Koskinen P, Virolainen J, Nikkila $\mathrm{H} \&$ White PC. Associations between human aldosterone synthase (CYP11B2) gene polymorphisms and left ventricular size, mass, and function. Circulation 199897 569-575. (doi:10.1161/ 01.CIR.97.6.569)

18 McManus F, Sands W, Diver L, MacKenzie SM, Fraser R, Davies E \& Connell JM. APEX1 regulation of aldosterone synthase gene transcription is disrupted by a common polymorphism in humans. Circulation Research $2012111212-219$. (doi:10.1161/CIRCRESAHA.111.262931)

19 Tamaki S, Iwai N, Tsujita Y \& Kinoshita M. Genetic polymorphism of CYP11B2 gene and hypertension in Japanese. Hypertension 199933 266-270. (doi:10.1161/01.HYP.33.1.266)

20 Tsukada K, Ishimitsu T, Teranishi M, Saitoh M, Yoshii M, Inada H, Ohta S, Akashi M, Minami J, Ono $\mathrm{H}$ et al. Positive association of CYP11B2 gene polymorphism with genetic predisposition to essential hypertension. Journal of Human Hypertension 200216 789-793. (doi:10.1038/sj.jhh.1001484)

21 Hautanena A, Lankinen L, Kupari M, Janne OA, Adlercreutz H, Nikkila H \& White PC. Associations between aldosterone synthase 
gene polymorphism and the adrenocortical function in males. Journal of Internal Medicine $1998 \mathbf{2 4 4} 11-18$. (doi:10.1046/ j.1365-2796.1998.00308.x)

22 Lim PO, Macdonald TM, Holloway C, Friel E, Anderson NH, Dow E, Jung RT, Davies E, Fraser R \& Connell JM. Variation at the aldosterone synthase (CYP11B2) locus contributes to hypertension in subjects with a raised aldosterone-to-renin ratio. Journal of Clinical Endocrinology and Metabolism 200287 4398-4402. (doi:10.1210/jc.2001-012070)

23 Sookoian S, Gianotti TF, Gonzalez CD \& Pirola CJ. Association of the $\mathrm{C}-344 \mathrm{~T}$ aldosterone synthase gene variant with essential hypertension: a meta-analysis. Journal of Hypertension 200725 5-13. (doi:10.1097/01.hjh.0000254372.88488.a9)

24 Hannemann A \& Wallaschofski H. Prevalence of primary aldosteronism in patient's cohorts and in population-based studies - a review of the current literature. Hormone and Metabolic Research 201244 157-162. (doi:10.1055/s-0031-1295438)

25 Sutherland DJ, Ruse JL \& Laidlaw JC. Hypertension, increased aldosterone secretion and low plasma renin activity relieved by dexamethasone. Canadian Medical Association Journal 196695 1109-1119.

26 New M. Hypertension of childhood with suppressed renin. Endocrine Reviews 19801 421-430. (doi:10.1210/edrv-1-4-421)

27 Lifton RP, Dluhy RG, Powers M, Rich GM, Cook S, Ulick S \& Lalouel JM. A chimaeric 11ß-hydroxylase aldosterone synthase gene causes glucocorticoid-remediable aldosteronism and human hypertension. Nature $1992355 \quad 262-265 . \quad$ (doi:10.1038/ $355262 \mathrm{a} 0)$

28 Pascoe L, Jeunemaitre X, Lebrethon MC, Curnow KM, GomezSanchez CE, Gasc JM, Saez JM \& Corvol P. Glucocorticoidsuppressible hyperaldosteronism and adrenal tumors occurring in a single French pedigree. Journal of Clinical Investigation 1995 96 2236-2246. (doi:10.1172/JCI118279)

29 Stowasser M, Bachmann AW, Huggard PR, Rossetti TR \& Gordon RD. Treatment of familial hyperaldosteronism type I: only partial suppression of adrenocorticotropin required to correct hypertension. Journal of Clinical Endocrinology and Metabolism 200085 3313-3318. (doi:10.1210/jc.85.9.3313)

30 Funder JW, Carey RM, Fardella C, Gomez-Sanchez CE, Mantero F, Stowasser M, Young WF Jr \& Montori VM. Case detection, diagnosis, and treatment of patients with primary aldosteronism: an Endocrine Society Clinical Practice Guideline. Journal of Clinical Endocrinology and Metabolism 200893 3266-3281. (doi:10. 1210/jc.2008-0104)

31 Mulatero P, Tizzani D, Viola A, Bertello C, Monticone S, Mengozzi G, Schiavone D, Williams TA, Einaudi S, La Grotta A et al. Prevalence and characteristics of familial hyperaldosteronism: the PATOGEN study (Primary Aldosteronism in TOrinoGENetic forms). Hypertension $2011 \mathbf{5 8} 797-803$. (doi:10.1161/ HYPERTENSIONAHA.111.175083)

32 Aglony M, Martinez-Aguayo A, Carvajal CA, Campino C, Garcia H, Bancalari R, Bolte L, Avalos C, Loureiro C, Trejo P et al. Frequency of familial hyperaldosteronism type 1 in a hypertensive pediatric population: clinical and biochemical presentation. Hypertension 201157 1117-1121. (doi:10.1161/ HYPERTENSIONAHA.110.168740)

33 Stowasser M, Gordon RD, Tunny TJ, Klemm SA, Finn WL \& Krek AL. Familial hyperaldosteronism type II: five families with a new variety of primary aldosteronism. Clinical and Experimental Pharmacology \& Physiology 199219 319-322. (doi:10.1111/ j.1440-1681.1992.tb00462.x)

34 Medeau V, Assie G, Zennaro MC, Clauser E, Plouin PF \& Jeunemaitre X. Familial aspect of primary hyperaldosteronism: analysis of families compatible with primary hyperaldosteronism type 2. Annales d'Endocrinologie 200566 240-246. (doi:10.1016/ S0003-4266(05)81756-1)

35 Stowasser M \& Gordon RD. Familial hyperaldosteronism. Journal of Steroid Biochemistry and Molecular Biology 200178 215-229. (doi:10.1016/S0960-0760(01)00097-8)

36 Gordon RD, Stowasser M, Tunny TJ, Klemm SA, Finn WL \& Krek AL. Clinical and pathological diversity of primary aldosteronism, including a new familial variety. Clinical and Experimental Pharmacology \& Physiology 199118 283-286. (doi:10.1111/j.1440-1681.1991.tb01446.x)

37 So A, Duffy DL, Gordon RD, Jeske YW, Lin-Su K, New MI \& Stowasser M. Familial hyperaldosteronism type II is linked to the chromosome $7 \mathrm{p} 22$ region but also shows predicted heterogeneity. Journal of Hypertension 200523 1477-1484. (doi:10.1097/01. hjh.0000174299.66369.26)

38 Sukor N, Mulatero P, Gordon RD, So A, Duffy D, Bertello C, Kelemen L, Jeske Y, Veglio F \& Stowasser M. Further evidence for linkage of familial hyperaldosteronism type II at chromosome 7 p22 in Italian as well as Australian and South American families. Journal of Hypertension 200826 1577-1582. (doi:10.1097/HJH. Ob013e3283028352)

39 Davies E, Bonnardeaux A, Plouin PF, Corvol P \& Clauser E. Somatic mutations of the angiotensin II (AT1) receptor gene are not present in aldosterone-producing adenoma. Journal of Clinical Endocrinology and Metabolism 199782 611-615. (doi:10.1210/ jc.82.2.611)

40 Ballantine DM, Klemm SA, Tunny TJ, Stowasser M \& Gordon RD. PCR-SSCP analysis of the promoter region of the renin gene in patients with aldosterone-producing adenomas. Clinical and Experimental Pharmacology \& Physiology 199623 584-586. (doi:10.1111/j.1440-1681.1996.tb02787.x)

41 Mulatero P, Tauber P, Zennaro MC, Monticone S, Lang K, Beuschlein F, Fischer E, Tizzani D, Pallauf A, Viola A et al. KCNJ5 mutations in European families with nonglucocorticoid remediable familial hyperaldosteronism. Hypertension $2012 \mathbf{5 9}$ 235-240. (doi:10.1161/HYPERTENSIONAHA.111.183996)

42 Geller DS, Zhang J, Wisgerhof MV, Shackleton C, Kashgarian M \& Lifton RP. A novel form of human Mendelian hypertension featuring nonglucocorticoid-remediable aldosteronism. Journal of Clinical Endocrinology and Metabolism 200893 3117-3123. (doi:10.1210/jc.2008-0594)

43 Choi M, Scholl UI, Yue P, Bjorklund P, Zhao B, Nelson-Williams C, Ji W, Cho Y, Patel A, Men CJ et al. $\mathrm{K}^{+}$channel mutations in adrenal aldosterone-producing adenomas and hereditary hypertension. Science 2011331 768-772. (doi:10.1126/science.1198785)

44 Oki K, Plonczynski MW, Luis Lam M, Gomez-Sanchez EP \& GomezSanchez CE. Potassium channel mutant KCNJ5 T158A expression in HAC-15 cells increases aldosterone synthesis. Endocrinology 2012153 1774-1782. (doi:10.1210/en.2011-1733)

45 Scholl UI, Nelson-Williams C, Yue P, Grekin R, Wyatt RJ, Dillon MJ, Couch R, Hammer LK, Harley FL, Farhi A et al. Hypertension with or without adrenal hyperplasia due to different inherited mutations in the potassium channel KCNJ5. PNAS 2012109 2533-2538. (doi:10.1073/pnas.1121407109)

46 Charmandari E, Sertedaki A, Kino T, Merakou C, Hoffman DA, Hatch MM, Hurt DE, Lin L, Xekouki P, Stratakis CA et al. A novel point mutation in the KCNJ5 gene causing primary hyperaldosteronism and early-onset autosomal dominant hypertension. Journal of Clinical Endocrinology and Metabolism 201297 E1532-E1539. (doi:10.1210/jc.2012-1334)

47 Heitzmann D, Derand R, Jungbauer S, Bandulik S, Sterner C, Schweda F, El Wakil A, Lalli E, Guy N, Mengual R et al. Invalidation of TASK1 potassium channels disrupts adrenal gland zonation and mineralocorticoid homeostasis. EMBO Journal 200827 179-187. (doi:10.1038/sj.emboj.7601934)

48 Davies LA, Hu C, Guagliardo NA, Sen N, Chen X, Talley EM, Carey RM, Bayliss DA \& Barrett PQ. TASK channel deletion in mice causes primary hyperaldosteronism. PNAS $2008 \mathbf{1 0 5}$ 2203-2208. (doi:10.1073/pnas.0712000105)

49 Penton D, Bandulik S, Schweda F, Haubs S, Tauber P, Reichold M, Cong LD, El Wakil A, Budde T, Lesage F et al. Task3 potassium channel gene invalidation causes low renin and salt-sensitive arterial hypertension. Endocrinology 2012153 4740-4748. (doi:10.1210/en.2012-1527)

50 Boulkroun S, Beuschlein F, Rossi GP, Golib-Dzib JF, Fischer E, Amar L, Mulatero P, Samson-Couterie B, Hahner S, Quinkler M 
et al. Prevalence, clinical, and molecular correlates of KCNJ5 mutations in primary aldosteronism. Hypertension $2012 \mathbf{5 9}$ 592-598. (doi:10.1161/HYPERTENSIONAHA.111.186478)

51 Azizan EA, Murthy M, Stowasser M, Gordon R, Kowalski B, $\mathrm{Xu} \mathrm{S}$, Brown MJ \& O'Shaughnessy KM. Somatic mutations affecting the selectivity filter of KCNJ5 are frequent in 2 large unselected collections of adrenal aldosteronomas. Hypertension 201259 587-591. (doi:10.1161/HYPERTENSIONAHA.111. 186239)

52 Akerstrom T, Crona J, Delgado Verdugo A, Starker LF, Cupisti K, Willenberg HS, Knoefel WT, Saeger W, Feller A, Ip J et al. Comprehensive re-sequencing of adrenal aldosterone producing lesions reveal three somatic mutations near the kcnj5 potassium channel selectivity filter. PLOS ONE 20127 e41926. (doi:10.1371/journal.pone.0041926)

53 Monticone S, Hattangady NG, Nishimoto K, Mantero F, Rubin B, Cicala MV, Pezzani R, Auchus RJ, Ghayee HK, Shibata H et al. Effect of KCNJ5 mutations on gene expression in aldosterone-producing adenomas and adrenocortical cells. Journal of Clinical Endocrinology and Metabolism 201297 E1567-E1572. (doi:10.1210/ jc.2011-3132)

54 Taguchi R, Yamada M, Nakajima Y, Satoh T, Hashimoto K, Shibusawa N, Ozawa A, Okada S, Rokutanda N, Takata D et al. Expression and mutations of KCNJ5 mRNA in Japanese patients with aldosterone-producing adenomas. Journal of Clinical Endocrinology and Metabolism 201297 1311-1319. (doi:10.1210/ jc.2011-2885)

55 Beuschlein F, Boulkroun S, Osswald A, Wieland T, Nielsen HN, Lichtenauer UD, Penton D, Schack VR, Amar L, Fischer E et al. Somatic mutations in ATP1A1 and ATP2B3 lead to aldosteroneproducing adenomas and secondary hypertension. Nature Genetics 201345 440-444. (doi:10.1038/ng.2550)

56 Murthy M, Azizan EA, Brown MJ \& O'Shaughnessy KM. Characterization of a novel somatic KCNJ5 mutation delI157 in an aldosterone-producing adenoma. Journal of Hypertension 201230 1827-1833. (doi:10.1097/HJH.0b013e328356139f)

57 Hastings MH, Reddy AB \& Maywood ES. A clockwork web: circadian timing in brain and periphery, in health and disease. Nature Reviews. Neuroscience 20034 649-661. (doi:10.1038/ nrn1177)

58 Matsuo T, Yamaguchi S, Mitsui S, Emi A, Shimoda F \& Okamura H. Control mechanism of the circadian clock for timing of cell division in vivo. Science $2003 \mathbf{3 0 2} 255-259$. (doi:10.1126/ science.1086271)

59 Kume K, Zylka MJ, Sriram S, Shearman LP, Weaver DR, Jin X, Maywood ES, Hastings MH \& Reppert SM. mCRY1 and mCRY2 are essential components of the negative limb of the circadian clock feedback loop. Cell 199998 193-205. (doi:10.1016/S00928674(00)81014-4)

60 van der Horst GT, Muijtjens M, Kobayashi K, Takano R, Kanno S, Takao M, de Wit J, Verkerk A, Eker AP, van Leenen D et al. Mammalian Cry 1 and Cry 2 are essential for maintenance of circadian rhythms. Nature 1999398 627-630. (doi:10.1038/ 19323)

61 Vitaterna MH, Selby CP, Todo T, Niwa H, Thompson C, Fruechte EM, Hitomi K, Thresher RJ, Ishikawa T, Miyazaki J et al. Differential regulation of mammalian period genes and circadian rhythmicity by cryptochromes 1 and 2. PNAS 199996 12114-12119. (doi:10.1073/pnas.96.21.12114)

62 Doi M, Takahashi Y, Komatsu R, Yamazaki F, Yamada H, Haraguchi S, Emoto N, Okuno Y, Tsujimoto G, Kanematsu A et al. Salt-sensitive hypertension in circadian clock-deficient Crynull mice involves dysregulated adrenal Hsd3b6. Nature Medicine 201016 67-74. (doi:10.1038/nm.2061)

63 Sugaya T, Nishimatsu S, Tanimoto K, Takimoto E, Yamagishi T, Imamura K, Goto S, Imaizumi K, Hisada Y, Otsuka A et al. Angiotensin II type 1a receptor-deficient mice with hypotension and hyperreninemia. Journal of Biological Chemistry $1995 \mathbf{2 7 0}$ 18719-18722. (doi:10.1074/jbc.270.32.18719)
64 Le TH, Kim HS, Allen AM, Spurney RF, Smithies O \& Coffman TM. Physiological impact of increased expression of the AT1 angiotensin receptor. Hypertension $2003 \mathbf{4 2}$ 507-514. (doi:10.1161/01.HYP. $0000092000.07559 .57)$

65 Billet S, Bardin S, Verp S, Baudrie V, Michaud A, Conchon S, Muffat-Joly M, Escoubet B, Souil E, Hamard G et al. Gainof-function mutant of angiotensin II receptor, type 1A, causes hypertension and cardiovascular fibrosis in mice. Journal of Clinical Investigation 2007117 1914-1925. (doi:10.1172/JCI28764)

66 Milliez P, Girerd X, Plouin PF, Blacher J, Safar ME \& Mourad JJ. Evidence for an increased rate of cardiovascular events in patients with primary aldosteronism. Journal of the American College of Cardiology 200545 1243-1248. (doi:10.1016/j.jacc.2005.01.015)

67 Freel EM, Mark PB, Weir RA, McQuarrie EP, Allan K, Dargie HJ, McClure JD, Jardine AG, Davies E \& Connell JM. Demonstration of blood pressure-independent noninfarct myocardial fibrosis in primary aldosteronism: a cardiac magnetic resonance imaging study. Circulation. Cardiovascular Imaging 20125 740-747. (doi:10.1161/CIRCIMAGING.112.974576)

68 Stowasser M, Sharman J, Leano R, Gordon RD, Ward G, Cowley D \& Marwick TH. Evidence for abnormal left ventricular structure and function in normotensive individuals with familial hyperaldosteronism type I. Journal of Clinical Endocrinology and Metabolism 200590 5070-5076. (doi:10.1210/jc.2005-0681)

69 Litchfield WR, Anderson BF, Weiss RJ, Lifton RP \& Dluhy RG. Intracranial aneurysm and hemorrhagic stroke in glucocorticoidremediable aldosteronism. Hypertension $1998 \quad 31$ 445-450. (doi:10.1161/01.HYP.31.1.445)

$70 \mathrm{Wu}$ VC, Chueh SC, Chang HW, Lin LY, Liu KL, Lin YH, Ho YL, Lin WC, Wang SM, Huang KH et al. Association of kidney function with residual hypertension after treatment of aldosteroneproducing adenoma. American Journal of Kidney Diseases 200954 665-673. (doi:10.1053/j.ajkd.2009.06.014)

71 Sechi LA, Novello M, Lapenna R, Baroselli S, Nadalini E, Colussi GL \& Catena C. Long-term renal outcomes in patients with primary aldosteronism. Journal of the American Medical Association 2006 295 2638-2645. (doi:10.1001/jama.295.22.2638)

72 Ribstein J, Du Cailar G, Fesler P \& Mimran A. Relative glomerular hyperfiltration in primary aldosteronism. Journal of the American Society of Nephrology 200516 1320-1325. (doi:10.1681/ASN. 2004100878)

73 Sechi LA, Di Fabio A, Bazzocchi M, Uzzau A \& Catena C. Intrarenal hemodynamics in primary aldosteronism before and after treatment. Journal of Clinical Endocrinology and Metabolism 2009 94 1191-1197. (doi:10.1210/jc.2008-2245)

74 Hollenberg NK. Aldosterone in the development and progression of renal injury. Kidney International 200466 1-9. (doi:10.1111/ j.1523-1755.2004.00701.x)

75 Utsumi T, Kawamura K, Imamoto T, Nagano H, Tanaka T, Kamiya N, Nihei N, Naya Y, Suzuki H \& Ichikawa T. Preoperative masked renal damage in Japanese patients with primary aldosteronism: identification of predictors for chronic kidney disease manifested after adrenalectomy. International Journal of Urology 2013. In press. (doi:10.1111/iju.12029)

76 Giacchetti G, Ronconi V, Turchi F, Agostinelli L, Mantero F, Rilli S \& Boscaro M. Aldosterone as a key mediator of the cardiometabolic syndrome in primary aldosteronism: an observational study. Journal of Hypertension 200725 177-186. (doi:10.1097/HJH. 0b013e3280108e6f)

77 Fallo F, Veglio F, Bertello C, Sonino N, Della Mea P, Ermani M, Rabbia F, Federspil G \& Mulatero P. Prevalence and characteristics of the metabolic syndrome in primary aldosteronism. Journal of Clinical Endocrinology and Metabolism 200691 454-459. (doi:10.1210/jc.2005-1733)

78 Mosso LM, Carvajal CA, Maiz A, Ortiz EH, Castillo CR, Artigas RA \& Fardella CE. A possible association between primary aldosteronism and a lower $\beta$-cell function. Journal of Hypertension 200725 2125-2130. (doi:10.1097/HJH.Ob013e3282861fa4)

79 Reincke M, Meisinger C, Holle R, Quinkler M, Hahner S, Beuschlein F, Bidlingmaier M, Seissler J \& Endres S. Is primary 
aldosteronism associated with diabetes mellitus? Results of the German Conn's Registry. Hormone and Metabolic Research 201042 435-439. (doi:10.1055/s-0029-1246189)

80 Matrozova J, Steichen O, Amar L, Zacharieva S, Jeunemaitre X \& Plouin PF. Fasting plasma glucose and serum lipids in patients with primary aldosteronism: a controlled cross-sectional study. Hypertension 200953 605-610. (doi:10.1161/HYPERTENSIONAHA.108.122002)

81 Catena C, Lapenna R, Baroselli S, Nadalini E, Colussi G, Novello M, Favret G, Melis A, Cavarape A \& Sechi LA. Insulin sensitivity in patients with primary aldosteronism: a follow-up study. Journal of Clinical Endocrinology and Metabolism 200691 3457-3463. (doi:10.1210/jc.2006-0736)

82 Boulkroun S, Golib Dzib JF, Samson-Couterie B, Rosa FL, Rickard AJ, Meatchi T, Amar L, Benecke A \& Zennaro MC. KCNJ5 mutations in aldosterone producing adenoma and relationship with adrenal cortex remodeling. Molecular and Cellular Endocrinology 2013371 221-227. (doi:10.1016/j.mce.2013. 01.018)

83 Azizan EA, Lam BY, Newhouse SJ, Zhou J, Kuc RE, Clarke J, Happerfield L, Marker A, Hoffman GJ \& Brown MJ. Microarray, qPCR, and KCNJ5 sequencing of aldosterone-producing adenomas reveal differences in genotype and phenotype between zona glomerulosa- and zona fasciculata-like tumors. Journal of Clinical Endocrinology and Metabolism 201297 E819-E829. (doi:10.1210/jc.2011-2965)

Received 14 September 2012

Revised version received 17 April 2013

Accepted 22 April 2013 